\title{
Animal Models of Alzheimer Disease
}

\author{
Frank M. LaFerla and Kim N. Green \\ Institute for Memory Impairments and Neurological Disorders, Department of Neurobiology and Behavior, \\ University of California, Irvine, Irvine, California 92697-4545 \\ Correspondence: laferla@uci.edu
}

Significant insights into the function of genes associated with Alzheimer disease and related dementias have occurred through studying genetically modified animals. Although none of the existing models fully reproduces the complete spectrum of this insidious human disease, critical aspects of Alzheimer pathology and disease processes can be experimentally recapitulated. Genetically modified animal models have helped advance our understanding of the underlying mechanisms of disease and have proven to be invaluable in the preclinical evaluation of potential therapeutic interventions. Continuing refinement and evolution to yield the next generation of animal models will facilitate successes in producing greater translational concordance between preclinical studies and human clinical trials and eventually lead to the introduction of novel therapies into clinical practice.

\begin{abstract}
$A^{\text {lzheimer disease }(\mathrm{AD}) \text {, the most common }}$ Acause of dementia, accounts for approximately two-thirds of all dementia cases and afflicts more than 35 million individuals worldwide, including more than 5.4 million Americans. It is a relentlessly progressive disorder that typically manifests initially by severe loss of memory, particularly of episodic memory. At present, the disorder is not curable, thereby increasing the urgency of developing and characterizing relevant animal models to facilitate translational research and preclinical drug development.

Research progress over the past two decades, including the elucidation of $\mathrm{AD}$ susceptibility and causative genes as well as other proteins involved in the pathogenic process, has profoundly facilitated the development of genetically altered mouse models (see http://www. alzforum.org/res/com/tra for a listing of cur-
\end{abstract}

rently available models). Animal models have played a major role in defining critical disease-related mechanisms and have been at the forefront of evaluating novel therapeutic approaches, with many treatments currently in clinical trial owing their origins to studies initially performed in mice. Nevertheless, there are significant translational issues that have been raised of late, as there has been some potential discordance between preclinical drug studies and human clinical trials.

\section{ASPECTS OF HUMAN AD MODELED IN TRANSGENIC MICE}

The vast majority of $\mathrm{AD}$ cases are sporadic (sAD), and the causes underlying these cases remain unknown. Neuropathologically, AD is characterized by the accumulation of amyloid$\beta(\mathrm{A} \beta)$ plaques and neurofibrillary tangles, in

Editors: Dennis J. Selkoe, Eckhard Mandelkow, and David M. Holtzman

Additional Perspectives on The Biology of Alzheimer Disease available at www.perspectivesinmedicine.org

Copyright (C) 2012 Cold Spring Harbor Laboratory Press; all rights reserved; doi: 10.1101/cshperspect.a006320

Cite this article as Cold Spring Harb Perspect Med 2012;2:a006320 
F.M. LaFerla and K.N. Green

addition to widespread synaptic loss, inflammation and oxidative damage, and neuronal death. Notably, the neuropathology and clinical phenotype are generally indistinguishable in the early-onset familial versus the sporadic form of the disease, with the biggest difference being the age of onset (Selkoe 2002). Because the etiology of idiopathic $\mathrm{AD}$ is unknown, animal models have relied on the utilization of genetic mutations associated with familial AD (fAD), with the rationale that the events downstream of the initial trigger are quite similar. These genetic models have still been invaluable in determining the molecular mechanisms of disease progression and for testing potential therapeutics. Although no single mouse model recapitulates all of the aspects of the disease spectrum, each model allows for in-depth analysis of one or two components of the disease, which is not readily possible or ethical with human patients or samples.

Transgenic mice overproducing mutant APP develop pathology that is similar to that found in the human brain; importantly, $A \beta$ accumulation into extracellular plaques occurs and is age-dependent-in other words, despite constant $A \beta$ production, plaques only occur in mid to late adulthood in the majority of these animals. Notably, plaque formation is accelerated when the longer $A \beta_{42}$ is preferentially cleaved from APP, as this peptide is more prone to aggregation than $A \beta_{40}$ and leads to earlier and more severe cognitive decline (reviewed in Findeis 2007). The importance of $A \beta_{42}$ to disease progression was highlighted by showing that elevated levels of $A \beta_{40}$, the shorter, more common form of $A \beta$, actually prevented the formation of $A \beta$ pathology in the widely used Tg2576 mouse model (McGowan et al. 2005). On the contrary, elevated levels of $A \beta_{42}$ markedly exacerbated pathology in the same mouse model.

$A \beta$ plaques found in the brains of $A D$ transgenic mice are structurally similar to those found in the human brain; they initiate as diffuse plaques consisting mainly of $A \beta_{42}$, develop a dense $A \beta_{42}$ core, and then incorporate $A \beta_{40}$, as well as numerous other non-A $\beta$ components such as ubiquitin and $\alpha$-synuclein (Yang et al. 2000). As in the human brain, these plaques stain positive with both thioflavin and Congo red, and show similar fibrillar structures by microscopy (Fig. 1).

Work in transgenic mice has highlighted the dynamic nature of extracellular plaques and has also aided in the clarification of important elements in both the brain environment and the $A \beta$ peptide needed for aggregation of $A \beta$ into plaques. Although formation of plaques in $\mathrm{AD}$ transgenic mice is typically age-dependent (as is $\mathrm{AD}$ pathology in humans), plaque formation occurs very quickly in the brains of older $\mathrm{AD}$

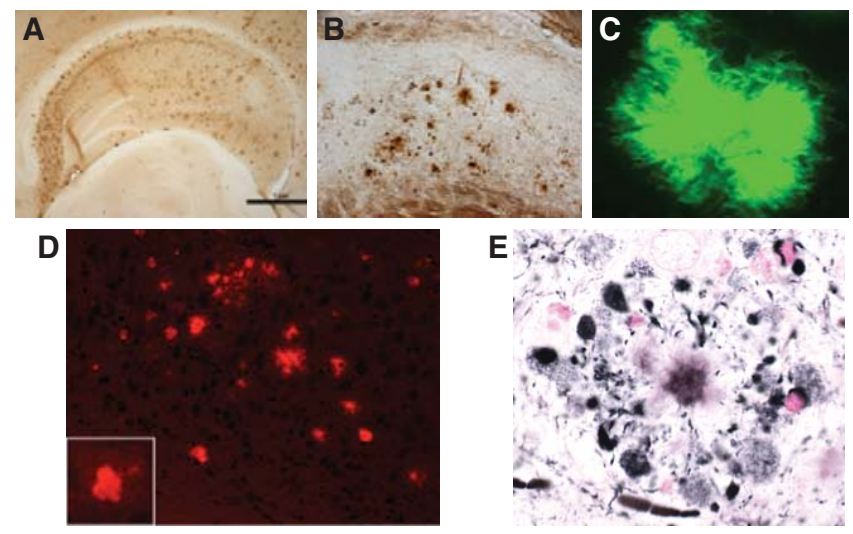

Figure 1. Visualization of amyloid plaques in 3xTg-AD mice with classical stains. 3xTg-AD mice develop diffuse and fibrillar plaques, as detected with antibody 6E10 $(A$ and $B)$, thioflavin-S $(C)$, Congo red $(D)$, and Gallyas stain $(E)$. 
transgenic mice. This has been shown using a window in the skull of APP transgenic mice (Meyer-Luehmann et al. 2008) and further supported by data that plaque volume in aged $\mathrm{AD}$ transgenic mice rapidly returns to high levels within 30 days following plaque removal by immunotherapy (Oddo et al. 2004), in grafts of wild-type tissue into $\mathrm{AD}$ transgenic mouse brains (Meyer-Luehmann et al. 2003), and in the brains of prepathologic $\mathrm{AD}$ transgenic mice following injection with brain extracts from human $\mathrm{AD}$ brain or aged $\mathrm{AD}$ transgenic mouse (Meyer-Luehmann et al. 2006). These data indicate that the adult AD transgenic mouse brain is ripe for the development of $A \beta$ pathology and the latter study also suggests that the ability of $A \beta$ to act as a seed for aggregation is dependent on its source.

Most AD transgenic models exhibit memory impairments, with the cognitive deficits appearing to occur earlier than the appearance of extracellular plaques. These observations led to a search for earlier pathological species of $\mathrm{A} \beta$ that could be mediating cognitive decline. Research shifted to identifying the precursors to plaque formation and identifying how aggregation of $A \beta$ was crucial to its toxicity. This led to the focus on soluble oligomeric $A \beta$ specieslow-molecular-weight aggregates up to $\sim 150$ $\mathrm{kDa}$ consisting of two to $30 \mathrm{~A} \beta$ peptides. As in $\mathrm{AD}$ transgenic mice, cognitive decline in humans is not proportional to $A \beta$ plaque load (Terry et al. 1991), but does correlate with soluble A $\beta$ species (Wang et al. 1999). However, in humans, unlike AD transgenic mice, cognitive decline does not begin until there is a large quantity of $\mathrm{A} \beta$ accumulation in the brain, including large amounts of amyloid plaques and probably oligomers. The latest data now indicate that soluble oligomeric species play a critical role in the pathogenicity of $\mathrm{AD}$ (for reviews, see Haass and Selkoe 2007; Walsh and Selkoe 2007). Evidence supporting involvement of soluble $\mathrm{A} \beta$ oligomers in $\mathrm{AD}$ is present in human postmortem brain tissue (Naslund et al. 2000; Kokubo et al. 2005); however, much of the evidence for the toxicity of oligomeric $A \beta$ and its central part in AD has come directly from the use of transgenic mouse models of $\mathrm{AD}$.
Intraneuronal $\mathrm{A} \beta$ has also gained experimental support in recent years (LaFerla et al. 2007). As in human $\mathrm{AD}$ and Down syndrome patients (who develop AD-like pathology by the fifth decade), many APP AD transgenic mice exhibit intraneuronal amyloid accumulation. The accumulation of intracellular $\mathrm{A} \beta$ has been shown to precede extracellular deposition in both human (Gyure et al. 2001; Mori et al. 2002) and some mouse studies (Oddo et al. 2003b). In fact, it was found in transgenic mice that intraneuronal $A \beta$ strongly correlates with initial deficits on a hippocampal-based memory task (Billings et al. 2005). Data from transgenic AD mice also indicate that intraneuronal $A \beta$ is more neurotoxic than extracellular $A \beta$ (Casas et al. 2004).

The other hallmark pathology of human AD are the intraneuronal aggregates of hyperphosphorylated tau known as neurofibrillary tangles (NFTs) (Fig. 2). The amyloid cascade hypothesis predicts that tau hyperphosphorylation occurs as a downstream consequence of $A \beta$ accumulation. APP-overexpressing transgenic mice have provided evidence both for and against this. Unlike humans with $\mathrm{AD}$, these mouse models do not develop NFTs, yet many do show increased tau hyperphosphorylation (reviewed in Gotz et al. 2007). This could be because (1) human $A \beta$ accumulation is not sufficient to cause NFT formation; (2) rodent tau has a different structure and sequence that may not be prone to aggregate formation; (3) the life span of mice is not prolonged enough to allow for enough hyperphosphorylation/aggregation as these pathologies develop over decades in humans; or (4) a combination of these. So whereas A $\beta$ accumulation in APP overexpressing mice does not lead to NFT formation, it should be remembered that these animals still develop robust cognitive decline and also undergo more subtle alterations in tau that resemble the precursors to NFTs in the human brain (most notably hyperphosphorylated tau).

To model the NFTs seen in human AD it has been necessary to develop transgenic mice that express further gene alterations in addition to mutated APP such as mutated human tau (Lewis et al. 2001; Oddo et al. 2003b) or removal 
F.M. LaFerla and K.N. Green
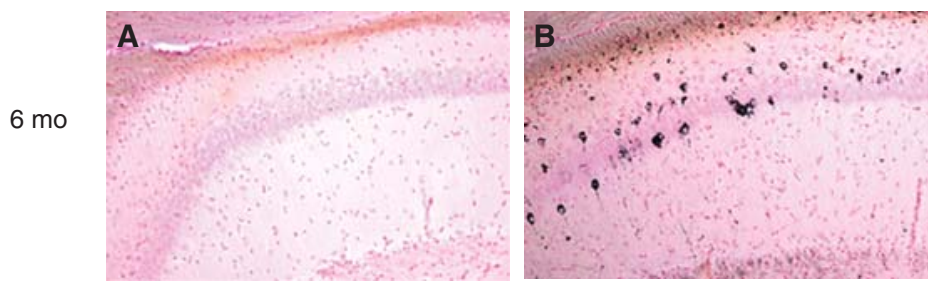

$12 \mathrm{mo}$
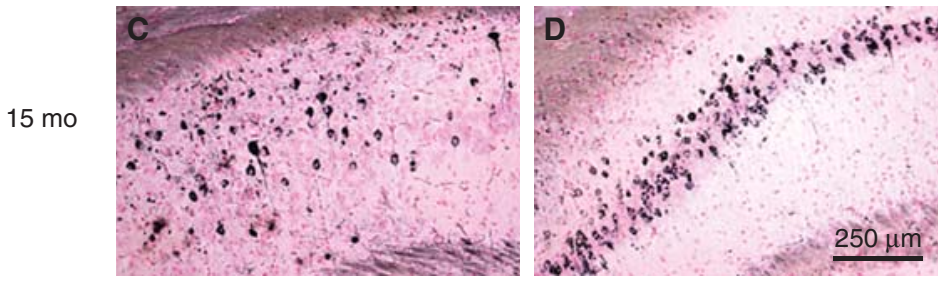

$24 \mathrm{mo}$

Figure 2. 3xTg-AD mice develop Gallyas-positive intraneuronal tangles. Age-dependent accumulation of Gallyas-positive aggregates within hippocampal neurons are observed in 3xTg-AD mice.

of nitric oxide synthase 2 (Wilcock et al. 2008). These multigenic $\mathrm{AD}$ transgenic models do develop NFTs similar to those seen in human brain and have aided the explication of the relationship between $A \beta$ and tau (reviewed in Blurton-Jones and LaFerla 2006) with A $\beta$ pathology seeming to precede the onset of tau pathology (Fig. 3), consistent with the amyloid cascade hypothesis. In addition to providing evidence that $A \beta$ accumulation occurs proximal to the onset of tau pathology, multigenic models of $\mathrm{AD}$ have also allowed us to determine how

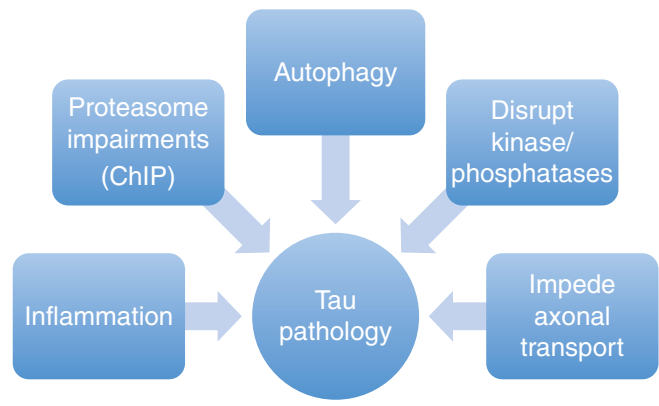

Figure 3. Pathways by which $A \beta$ facilitates tau pathology. Several pathways have been implicated in the hyperphosphorylation and aggregation of tau in neurons. These include inflammation, proteasome impairments, impairments in autophagy, increased kinase activity, and decreased phosphatase activity, as well as impeded axonal transport. manipulation of $A \beta$ affects tau and vice versa. Some of the strongest data supporting tau pathology as a downstream event of $A \beta$ accumulation have come from the study of these mice. For example, in the $3 \mathrm{xTg}-\mathrm{AD}$ mice, which contain human APP, PS1, and tau mutant transgenes, appearance of intraneuronal $\mathrm{A} \beta$ precedes somatodendritic accumulation of tau (Oddo et al. 2003a). Furthermore, removal of intraneuronal $A \beta$ via immunotherapy leads to the removal of somatodendritic tau shortly afterward, providing the tau is not aggregated (Oddo et al. 2004). It was also found that $A \beta$ oligomers inhibit proteasome function, which normally serves to degrade excess tau proteins, leading to tau accumulation (reviewed in (Oddo 2008). Such impairments in proteasome activity have been shown in human $\mathrm{AD}$ as well (Keller et al. 2000).

A further connection between $A \beta$ aggregation and downstream pathologies, such as tau, exists in the inflammatory response present in AD. Inflammation in $\mathrm{AD}$ is not exactly modeled in mice, as there are differences between humans and $\mathrm{AD}$ transgenic mice with respect to the nature and severity of the inflammation (Webster et al. 1999; Mehlhorn et al. 2000), yet $\mathrm{AD}$ transgenic mice are still valuable for revealing which aspects of inflammation may be key for the development or elimination of downstream pathologies. Data from $\mathrm{AD}$ transgenic 
mice indicate that inflammation, including activation of complement and various cytokines, occurs downstream from the aggregation of $\mathrm{A} \beta$ (reviewed in Akiyama et al. 2000), and more specifically, in association with fibrillar $A \beta$ (Kitazawa et al. 2005). Many of these inflammatory mediators that are up-regulated by $\mathrm{A} \beta$ can serve to increase tau pathology (reviewed in Blurton-Jones and LaFerla 2006). For example, activation of Cdk5 following an inflammatory response leads to tau hyperphosphorylation (Kitazawa et al. 2005). There is also production of reactive oxygen species as a result of this inflammatory response (Steele et al. 2007), which is damaging to cell membranes and may further exacerbate the inflammatory response. In both humans and $\mathrm{AD}$ transgenic mice, $\mathrm{A} \beta$ plaques are surrounded by activated microglia and astrocytes; thus even as the activation of the inflammatory response in $\mathrm{AD}$ can lead to the detrimental effects discussed above, activated microglia act in a beneficial manner by attempting to phagocytose $A \beta$ plaques (WyssCoray and Mucke 2002). In support of the hypothesis that inflammation may have favorable effects in $\mathrm{AD}$, acute inflammation, as brought about by treatment with lipopolysaccharide (LPS), has been shown to clear $A \beta$ plaques (DiCarlo et al. 2001) in AD transgenic mice, whereas more chronic LPS treatment potentiates tau pathology (Kitazawa et al. 2005). Active and passive immunotherapy strategies using $A \beta$ or antibodies against $A \beta$, respectively, have also proven useful in reducing plaque and, subsequently, tangle pathology as well as cognitive deficits in $\mathrm{AD}$ transgenic mice. The stimulation of microglia is one mechanism that appears to be involved in the reduction of plaque burden (reviewed in Morgan 2006) and further supports the idea that an inflammatory response in the $\mathrm{AD}$ brain has some positive effects.

\section{MODELS BASED ON GENE ABLATION}

In addition to transgenic mouse models, which overproduce and recapitulate the $A \beta$ and tau pathologies that are associated with $\mathrm{AD}$, numerous genetically modified mice have been produced that lack genes associated with this disorder. Although these mice do not recapitulate the human pathological phenotype per se, they have proven useful in elucidating the molecular mechanisms underlying the pathology, as well as identifying some of the other pathways that are the targets of crucial drugs. Specifically, knockout mice have been made of the APP secretases (BACE, presenilin [1 and 2], and ADAM 10 and 17; Shen et al. 1997; Herreman et al. 1999; Luo et al. 2001; Hartmann et al. 2002; Lee et al. 2003). In addition, both APP and tau knockout mice have proven invaluable in understanding disease progression, as well as in identifying physiological roles for the APP protein (Zheng et al. 1996; Takei et al. 2000).

The presenilins were identified as being a crucial component of $\gamma$-secretase in 1995, and their presence necessary for the production of $\mathrm{A} \beta$. As such, the presenilins and the $\gamma$-secretase complex quickly became the primary small molecular drug target for AD. Presenilin 1 knockout mice were produced in 1997, and it was shown that homozygous knockout of PS1 was lethal, with developmental defects in both the central nervous system (CNS) and skeletal systems (Shen et al. 1997). Hence, the production of these mice were the first indications that presenilin, and the $\gamma$-secretase complex, had vital roles outside of the production of $\mathrm{A} \beta$, and that inhibiting it may lead to undesirable off-target effects. Despite these early indications, and a wealth of subsequent publications showing numerous substrates for the $\gamma$-secretase complex (Beel and Sanders 2008), regulating many signaling pathways - including suppression of skin cancer (Zhang et al. 2007), as well as roles in calcium dyshomeostasis (Green and LaFerla 2008) and autophagy (Lee et al. 2010; Neely et al. 2011)-efforts progressed toward developing $\gamma$-secretase inhibitors and a great number of highly specific compounds were identified. These inhibitors have recently been tested in phase III clinical trials, and consistent with the wealth of data obtained from presenilin knockout mice, one of these was found to cause increased cognitive decline, and increased the incidence of skin cancer (Schor 2011). As such these inhibitor 
F.M. LaFerla and K.N. Green

programs have largely been abandoned in preference for more APP selective $\gamma$-secretase inhibitors, or $\gamma$-secretase modulators, which do not inhibit the $\gamma$-secretase complex, but alter where it cleaves APP to generate less aggregate-prone species of $A \beta$.

BACE1 is the sole $\beta$-secretase enzyme, and its activity is also crucial for the production of A $\beta$. Several groups first identified it in 1999 (Hussain et al. 1999; Sinha et al. 1999; Vassar et al. 1999), but its physiological functions were unclear. As with presenilin and the $\gamma$-secretase complex, its cloning and identification made the creation of BACE inhibitor programs a primary target for the treatment of $\mathrm{AD}$. Contrary to presenilin-deficient mice, BACE1 knockout mice were found to be healthy and viable with no obvious defects (Luo et al. 2001; Roberds et al. 2001) and, importantly, no longer produced any $\mathrm{A} \beta$. Thus, BACE1 appears a much more attractive drug target that the $\gamma$-secretase complex owing to a lack of obvious deficits when its activity is ablated. As proof of concept that targeting of BACE1 for the treatment of $\mathrm{AD}$ would be effective, BACE1 knockout mice were crossed with the Tg2576 mice. The absence of BACE1 prevented cognitive decline in these animals and markedly reduced $A \beta$ levels (Ohno et al. 2004). These BACE1 knockout mice have also been used to identify substrates other than APP and have highlighted $\beta$ subunits of voltage-gated sodium channels (Dominguez et al. 2005; Wong et al. 2005; Kim et al. 2011), klotho (Bloch et al. 2009), and neuregulin-1 (Hu et al. 2006; Willem et al. 2006), which is essential for myelination of both peripheral and central neurons. Hence, BACE1 appears to have a role in the developmental myelination of the nervous system, with BACE1 knockout mice showing significantly reduced levels of myelination and myelin thickness (Hu et al. 2006; Willem et al. 2006). Further analyses revealed that BACE1 knockout mice had increased pain sensitivity and reduced grip strength ( $\mathrm{Hu}$ et al. 2006). However, these deficits may be due to developmental issues that do not arise when BACE1 is ablated or inhibited in the developed/aged organism, and thus far, no conditional BACE1 knockout mice exist to test this issue. Peripheral remyelination has been investigated in mature BACE1 knockout mice and has been shown to be impaired (Hu et al. 2008), yet axonal regeneration is enhanced following axotomy (Farah et al. 2011), suggesting a possible unwanted side effect of systemically administered BACE1 inhibitors.

Related to these deficits in myelination in BACE1 knockout a mouse, careful reanalysis has revealed subtle deficits in prepulse inhibition, hypersensitivity to a glutamatergic psychostimulant, cognitive impairments, and reduced dendritic spine densities (Laird et al. 2005; Savonenko et al. 2008). Collectively, BACE1 knockout mice have established BACE1 as a primary target for the treatment of $\mathrm{AD}$ with minimal off-target effects, but have highlighted its role in both myelination and regulation of the levels of voltagegated sodium channels, suggesting that there could be some deleterious side effects from inhibiting BACE1 in the mature body/CNS. Regardless, inhibiting BACE1 in the adult brain appears to be far less problematic than inhibiting the presenilins and the $\gamma$-secretase complex, and remains a far safer target.

Given the information gleaned from BACE1 knockout mice, why is it that a $\gamma$-secretase inhibitor has been through a phase III clinical trial, whereas no BACE1 inhibitor results have come to light? This appears to be due to limitations of the compounds discovered thus far. BACE1 has a large active site, and it has been challenging to find compounds that cross the blood-brain barrier and are large enough to inhibit the active site without being broken down by endopeptidases (Huang et al. 2009). However, some promising compounds have been reported to lower $A \beta$ levels in transgenic mice (Chang et al. 2004; Hussain et al. 2007; Fukumoto et al. 2010; Lerchner et al. 2010) and primates (Sankaranarayanan et al. 2009), and human clinical trials are ensuing.

Tau knockout mice have shed light on the mechanism by which $A \beta$ induces cognitive deficits in APP transgenic models. Curiously, plaque load does not correlate well with cognitive decline in AD patients (Nagy et al. 1995), whereas cognitive deficits are detected in most APP transgenic mice prior to plaque deposition 
(Billings et al. 2005). Furthermore, the involvement of tau in the pathogenesis of AD has never been fully understood-mutations in APP or presenilin lead to $\mathrm{AD}$, but mutations in tau lead to their own neurodegenerative diseases. Tau becomes hyperphosphorylated during the $\mathrm{AD}$ process, and aggregates into NFTs. Many lines of evidence indicate that the presence of A $\beta$ pathologies can activate kinases, downregulate phosphatases, and impair degradation of tau, leading to tau pathology (Blurton-Jones and LaFerla 2006). However, what is the consequence of these tau pathologies on cognition and neuronal/synaptic loss, compared with the consequences of A $\beta$ pathology alone? Notably, it has been shown that crossing APP transgenic mice onto a tau knockout background prevents all cognitive deficits associated with the presence of APP and A (Roberson et al. 2007), including reduced spontaneous seizures (Palop et al. 2007) and long-term potentiation (LTP; Shipton et al. 2011). The absence of tau has no effect on the development of $A \beta$ pathologies, including plaque load. Hence, endogenous murine tau is necessary for APP and A $\beta$ to mediate its effects on cognition, LTP and hyperexcitibility of neurons. These exciting discoveries have shed light on the crucial role that tau may play in directly mediating the effects of $A \beta$ on cognition and other adverse effects. Notably, APP transgenic mice do not develop extensive tau pathologies on their own-some hyperphosphorylation is seen, but the tau remains soluble and does not resemble the NTFs found in the human disease. Hence, soluble tau may be more important to the disease process than tau that has aggregated into NFTs. During the disease process, the axonal protein tau becomes mislocalized to the soma and dendrites. Accumulation of tau within the dendritic spines impairs synaptic function (Hoover et al. 2010), but only when the tau is phosphorylated. It has been shown that tau present in the dendrites can target the protein kinase Fyn to the postsynaptic membranes (Ittner et al. 2010). Once there, it phosphorylates the NR2b subunit of the NMDA ( $N$-methyl-Daspartate) receptor, causing it to stabilize with PSD-95. This stabilization leads to a greater influx of calcium through the NMDA receptor and can be synaptotoxic. Notably, A $\beta$ oligomers can interact with NMDA receptors and so it may be the combined effects of both $A \beta$ and tau that drive the effects at the synapse and lead to impaired cognition, LTP, hyperexcitibility, and changes in dendritic spine morphology and density. Hence, the use of tau knockout mice, if the effects seen are relevant to human $\mathrm{AD}$, has radically changed our understanding of the role of tau in disease progression, and the nature of the relationship between $A \beta$ and tau and their effects on cognition. Importantly, these studies and mice have highlighted an important role for tau outside of $\mathrm{AD}$, but more generally in excitotoxicity.

\section{TRANSLATIONAL ISSUES}

More than 15 years have passed since the first transgenic models were derived that recapitulated aspects of AD pathology. Somewhat surprisingly, since that time, no new therapies for $\mathrm{AD}$ have been approved and introduced into the clinic, and the two currently approved drug classes (acetylcholinesterase inhibitors and memantine) were not tested in these transgenic mice prior to the clinic. This stark reality begs the question of how useful have these animal models actually been for the field? Have they been a distraction to the real issues facing an $\mathrm{AD}$ patient, or will their continued use bear fruits over the coming years? Why have so many therapies and interventions been successful in these models, but have universally failed when evaluated in clinic trials? Although an in-depth discussion of these questions is beyond the scope of this review, we will touch on some of the translational issues (Box 1).

The most widely used animal models in the field are in fact models based on the genetics of familial $\mathrm{AD}$. Less than $1 \%$ of $\mathrm{AD}$ cases are due to autosomal-dominant $\mathrm{AD}$, rather than sporadic $\mathrm{AD}$, so the obvious initial question is whether fAD and SAD are the same phenotypical disease or are there subtle differences between the pathologies that would allow a treatment to work in one but not the other. By all pathological counts, they are essentially 
F.M. LaFerla and K.N. Green

\section{BOX 1. TRANSLATIONAL CONCERNS WITH ANIMAL MODELS}

- There is lack of concordance between preclinical models and human clinical trials.

- Potential reasons: wrong targets, incomplete models, lack of variability among individuals in the models, patients enrolled too late, comorbidities

- Humans enrolled in clinical trials are heterogenous, whereas most models utilize in-bred stains on mice.

- Potential solution: evaluating novel treatments in multiple lines may help address this point

- There is lack of substantial cell and synaptic loss in the majority of rodent models, suggesting the models better represent the prodromal phase of the disease.

- Models are of familial AD, and most people have sporadic AD.

the same disease, with abundant plaque and tangle accumulations in the same brain areas as well as high levels of synaptic and neuronal loss. The differences appear to be what causes the buildup of the pathologies in the first place. In $\mathrm{fAD}$, a mutation in APP or PS $1 / 2$ causes the accumulation of $A \beta$, whereas the causes of $\mathrm{A} \beta$ accumulation in $\mathrm{SAD}$ are unclear, but likely to be a combination of genetic and environmental factors. Both are highly influenced by aging, with fAD manifesting at younger ages, and being more aggressive in its progression. A priori, one could postulate that fAD might be harder to treat than $\mathrm{SAD}$, because of the aggressiveness of the pathology. Hence, transgenic mice that model $\mathrm{fAD}$, and do so in a very short time frame (1-2 years) should be the hardest to treat, and should therefore translate to sAD very effectively. Obviously, the plethora of numerous failed clinical trials indicates that this is not the case, and so why do so many treatments show success in these aggressive mouse models of fAD and then fail in patients with $\mathrm{SAD}$ ?

Although there are numerous hypotheses that may account for the discordance in results between preclinical animal models and human clinical trials, no doubt one of the most significant may be that many AD models do not recapitulate the extensive neuronal loss observed in the human condition. Human imaging studies and clinical-pathological studies show that patients with mild-moderate $\mathrm{AD}$ already have not only brain atrophy but also extensive neuronal loss in several brain regions. The therapies that are being pioneered in mouse models are primarily targeting the pathologies modeled and not dealing with the issue of extensive neuronal loss. Hence, many of these therapies may be effective at preventing or clearing the pathology, and hence the disease, but are ineffective in people in which the pathology has already destroyed a huge proportion of the neurons that they need for memories and cognition. The acetylcholinesterase inhibitors were developed following studies identifying cholinergic loss as being a highly important factor in $\mathrm{AD}$ cognitive decline.

This raises two pertinent questions: First, why do mice not recapitulate the neuronal loss seen in the disease, and, second, can we develop models that do develop similar loss in which therapeutics can be evaluated? We believe that the fundamental reason why transgenic mice do not develop extensive neuronal loss, like human $\mathrm{AD}$ patients, is the amount of time needed. In human $\mathrm{AD}$, disease progresses over decades. During this time synaptic disturbances, such as those measured in transgenic mice, could eventually lead to neuronal death. The two years during which we keep most transgenic APP mice may not be long enough for this to occur. Other issues also clearly play a role, such as background strains, such as the widely used C57/Bl6, which may be more resistant to excitotoxicity and heterogeneity of humans versus inbred mouse strains, as well as fundamental differences between mice and humans. For example, it is well established that APP transgenic mice have cognitive decline prior to plaques, 
and prior to any measurable neuronal loss. Furthermore, $A \beta$ oligomers have been universally shown to impair LTP in countless studies, and it is easy to then connect this to the cognitive impairments seen in these mice. Yet there is no evidence that $A \beta$ causes cognitive decline in humans prior to plaques (and neuronal loss). If A $\beta$ impairs LTP in the human brain in the same, robust, fashion that it does in the rodent brain then presumably humans would experience cognitive decline in the absence of both plaques and neuronal loss whenever $A \beta$ oligomers could first be detected (Kuo et al. 1996; Tomic et al. 2009; Woltjer et al. 2009), and this cannot be explained by cognitive reserve. This has not yet been shown to occur, suggesting that it is possible that $A \beta$ may have different modes of action in the rodent brain compared with that of a human.

So how do we develop therapies that target the neuronal loss and how do we then test and validate them in vivo, prior to the clinic? Clinical trials for $\mathrm{AD}$ are expensive- - upward of $\$ 10$ 20 million for a well-powered phase II/III trial. Hence, only the most promising compounds can be brought into the clinic, and every failure is costly and discouraging to alternative future trials. It should be noted that prevention trials have not yet been feasible, in part owing to a lack of biomarkers and the extreme expense associated with the numbers of people needed and the amount of time for which they would have to be evaluated, and therefore trials have only used cognitive outcome measures in usually mild-moderate AD patients-which means they already have extensive plaque and tangle loads, and that these have already caused extensive neuronal damage and loss, which in turn causes dementia. We have developed a novel approach to this problem by using an inducible transgenic mouse model of neuronal loss (Yamasaki et al. 2007). We use the tetracyclineoff system to drive expression of diptheria toxin A chains in neurons under control of the Calmodulin Kinase II promoter. By withdrawing doxycycline from the diet, we can specifically ablate neurons in regions of the brain that are impacted in $\mathrm{AD}$, and we can titrate that loss to levels seen in the $\mathrm{AD}$ brain. Mice show cognitive impairments, as expected, and can then be used to identify treatments that can improve cognition in the presence of extensive neuronal loss, such as that seen in $\mathrm{AD}$ patients. We are taking the approach of combining therapy testing in this model alongside a traditional APP/tau transgenic mouse, such as the $3 \mathrm{xTg}-\mathrm{AD}$, to identify treatments that can improve cognition in the presence of $A \beta$ and tau pathologies, but also neuronal loss. This ensures that only the best therapies will be selected and proposed as clinical candidates.

If 15 years of using transgenic mouse models of $\mathrm{AD}$ have yielded no positive clinical results, then have these mice been a failure or even a distraction from the real problems with $\mathrm{AD}$ ? The answer is unequivocally no-many novel approaches to reducing AD pathology have been discovered and developed in these transgenic mice, and will probably progress into successful clinical trials when we find ways to target prodromal stages of the disease through biomarkers, or attempt prevention. It is through these approaches that we will one day be able to prevent the occurrence of the disease as we age. For example, immunotherapy was developed in APP transgenic mice and could not have been proven to clear pathology without them. Immunotherapy has progressed into numerous clinical trials and has been shown to reduce both $A \beta$ and tau levels in patients (Boche et al. 2010), as shown in mouse models (Schenk et al. 1999; Oddo et al. 2004). The effects on cognition have been mixedbenefits have been seen in patients without the apos 4 allele, but not in those with apoe4which accounts for $\sim 60 \%$ of patients. As targeting the plaques does nothing to address the extensive neuronal loss that has occurred in these patients, hints of effects on cognition are extremely promising. We would predict, from this, that immunization as an $\mathrm{AD}$ preventative may be effective. Furthermore, encephalitis caused by immunotherapy in a small cohort of patients may not occur before abundant $A \beta$ deposits are found throughout the brain.

Other potential therapeutics developed in $\mathrm{AD}$ transgenic mice may yet show clinical success, either as preventatives or as treatments. 
F.M. LaFerla and K.N. Green

Some promising approaches include the copper/zinc chelator PBT2 (Adlard et al. 2008), which has shown efficacy in phase II clinical trials (Faux et al. 2010), and scyllo-inositol (McLaurin et al. 2006), which breaks up A $\beta$ oligomers. Many companies are now exploring potential cognitive enhancers in $\mathrm{AD}$ transgenics, such as $\alpha 7$ agonists (Marighetto et al. 2008), phosphodiesterase inhibitors (Puzzo et al. 2009; Verhoest et al. 2009), H3 antagonists (Medhurst et al. 2007), and other approaches. Perhaps targeting cognitive decline in the presence of pathology will be more successful than targeting the pathology alone, which has been the trend of the past decade, or using a combination approach.

\section{CONCLUSIONS}

What will the next generation of transgenic models of AD bring, and how can they be developed to help develop therapeutics and preventatives for sporadic AD? A new era will be ushered in as other types of animal models are produced. For example, there may be advantages to moving away from mice and rats and genetically modifying other smaller animal species, particularly those in which the endogenous $\mathrm{A} \beta$ sequence is identical to humans and those in which processing of tau is more closely aligned to humans. In addition, we need to find ways to model sporadic $\mathrm{AD}$, rather than familial $\mathrm{AD}$. This means that the animals will need to develop pathology because they age, rather than because their genes program them to do so. Once such an animal is produced we will be able to study which aspects of the aging process drive the pathology in the first place, and then target them for prevention. We have already proposed using alternative models of neuronal loss to supplement AD pathology models, and think that this is also a good approach. Making such models will be challenging and will require a great deal of investment, both time and financial, and not all approaches will work. However, we need to improve on the current batch of $\mathrm{AD}$ transgenics and look to future so that we will be able to treat and prevent this insidious disease.

\section{REFERENCES}

Adlard PA, Cherny RA, Finkelstein DI, Gautier E, Robb E, Cortes M, Volitakis I, Liu X, Smith JP, Perez K, et al. 2008. Rapid restoration of cognition in Alzheimer's transgenic mice with 8 -hydroxy quinoline analogs is associated with decreased interstitial Aß. Neuron 59: 43-55.

Akiyama H, Barger S, Barnum S, Bradt B, Bauer J, Cole GM, Cooper NR, Eikelenboom P, Emmerling M, Fiebich BL, et al. 2000. Inflammation and Alzheimer's disease. Neurobiol Aging 21: 383-421.

Beel AJ, Sanders CR. 2008. Substrate specificity of $\gamma$-secretase and other intramembrane proteases. Cell Mol Life Sci 65: 1311-1334.

Billings LM, Oddo S, Green KN, McGaugh JL, LaFerla FM. 2005. Intraneuronal $A \beta$ causes the onset of early Alzheimer's disease-related cognitive deficits in transgenic mice. Neuron 45: 675-688.

Bloch L, Sineshchekova O, Reichenbach D, Reiss K, Saftig P, Kuro-o M, Kaether C. 2009. Klotho is a substrate for $\alpha$-, $\beta$ - and $\gamma$-secretase. FEBS Lett 583: 3221-3224.

Blurton-Jones M, LaFerla FM. 2006. Pathways by which A $\beta$ facilitates tau pathology. Curr Alzheimer Res 3: 437-448.

Boche D, Denham N, Holmes C, Nicoll JA. 2010. Neuropathology after active $A \beta 42$ immunotherapy: Implications for Alzheimer's disease pathogenesis. Acta Neuropathol 120: $369-384$.

Casas C, Sergeant N, Itier JM, Blanchard V, Wirths O, van der Kolk N, Vingtdeux V, van de Steeg E, Ret G, Canton T, et al. 2004. Massive CA1/2 neuronal loss with intraneuronal and $\mathrm{N}$-terminal truncated $\mathrm{A} \beta 42$ accumulation in a novel Alzheimer transgenic model. Am J Pathol 165: 1289-1300.

Chang WP, Koelsch G, Wong S, Downs D, Da H, Weerasena V, Gordon B, Devasamudram T, Bilcer G, Ghosh AK, et al. 2004. In vivo inhibition of $A \beta$ production by memapsin 2 ( $\beta$-secretase) inhibitors. J Neurochem 89: 1409-1416.

DiCarlo G, Wilcock D, Henderson D, Gordon M, Morgan D. 2001. Intrahippocampal LPS injections reduce $A \beta$ load in APP + PS1 transgenic mice. Neurobiol Aging 22: $1007-1012$.

Dominguez D, Tournoy J, Hartmann D, Huth T, Cryns K, Deforce S, Serneels L, Camacho IE, Marjaux E, Craessaerts K, et al. 2005. Phenotypic and biochemical analyses of BACE1- and BACE2-deficient mice. J Biol Chem 280: 30797-30806.

Farah MH, Pan BH, Hoffman PN, Ferraris D, Tsukamoto T, Nguyen T, Wong PC, Price DL, Slusher BS, Griffin JW. 2011. Reduced BACE1 activity enhances clearance of myelin debris and regeneration of axons in the injured peripheral nervous system. J Neurosci 31: 5744-5754.

Faux NG, Ritchie CW, Gunn A, Rembach A, Tsatsanis A, Bedo J, Harrison J, Lannfelt L, Blennow K, Zetterberg $\mathrm{H}$, et al. 2010. PBT2 rapidly improves cognition in Alzheimer's disease: Additional phase II analyses. J Alzheimers Dis 20: 509-516.

Findeis MA. 2007. The role of amyloid $\beta$ peptide 42 in Alzheimer's disease. Pharmacol Ther 116: 266-286.

Fukumoto H, Takahashi H, Tarui N, Matsui J, Tomita T, Hirode M, Sagayama M, Maeda R, Kawamoto M, Hirai K, 
et al. 2010. A noncompetitive BACE1 inhibitor TAK-070 ameliorates $A \beta$ pathology and behavioral deficits in a mouse model of Alzheimer's disease. J Neurosci 30: 11157-11166.

Gotz J, Deters N, Doldissen A, Bokhari L, Ke Y, Wiesner A, Schonrock N, Ittner LM. 2007. A decade of tau transgenic animal models and beyond. Brain Pathol 17: 91-103.

Green KN, LaFerla FM. 2008. Linking calcium to $A \beta$ and Alzheimer's disease. Neuron 59: 190-194.

Gyure KA, Durham R, Stewart WF, Smialek JE, Troncoso JC. 2001. Intraneuronal a $\beta$-amyloid precedes development of amyloid plaques in Down syndrome. Arch Pathol Lab Med 125: 489-492.

Haass C, Selkoe DJ. 2007. Soluble protein oligomers in neurodegeneration: Lessons from the Alzheimer's amyloid ß-peptide. Nat Rev Mol Cell Biol 8: 101-112.

Hartmann D, de Strooper B, Serneels L, Craessaerts K, Herreman A, Annaert W, Umans L, Lubke T, Lena Illert A, von Figura K, et al. 2002. The disintegrin/metalloprotease ADAM 10 is essential for Notch signalling but not for $\alpha$-secretase activity in fibroblasts. Human Mol Genet 11: 2615-2624.

Herreman A, Hartmann D, Annaert W, Saftig P, Craessaerts K, Serneels L, Umans L, Schrijvers V, Checler F, Vanderstichele H, et al. 1999. Presenilin 2 deficiency causes a mild pulmonary phenotype and no changes in amyloid precursor protein processing but enhances the embryonic lethal phenotype of presenilin 1 deficiency. Proc Natl Acad Sci 96: 11872-11877.

Hoover BR, Reed MN, Su J, Penrod RD, Kotilinek LA, Grant MK, Pitstick R, Carlson GA, Lanier LM, Yuan LL, et al. 2010. Tau mislocalization to dendritic spines mediates synaptic dysfunction independently of neurodegeneration. Neuron 68: 1067-1081.

Hu X, Hicks CW, He W, Wong P, Macklin WB, Trapp BD, Yan R. 2006. Bace1 modulates myelination in the central and peripheral nervous system. Nat Neurosci 9: 1520-1525.

Hu X, He W, Diaconu C, Tang X, Kidd GJ, Macklin WB, Trapp BD, Yan R. 2008. Genetic deletion of BACE1 in mice affects remyelination of sciatic nerves. FASEB J 22 2970-2980.

Huang WH, Sheng R, Hu YZ. 2009. Progress in the development of nonpeptidomimetic BACE 1 inhibitors for Alzheimer's disease. Curr Med Chem 16: 1806-1820.

Hussain I, Powell D, Howlett DR, Tew DG, Meek TD, Chapman C, Gloger IS, Murphy KE, Southan CD, Ryan DM et al. 1999. Identification of a novel aspartic protease (Asp 2) as $\beta$-secretase. Mol Cell Neurosci 14: 419-427.

Hussain I, Hawkins J, Harrison D, Hille C, Wayne G, Cutler L, Buck T, Walter D, Demont E, Howes C, et al. 2007. Oral administration of a potent and selective non-peptidic BACE-1 inhibitor decreases $\beta$-cleavage of amyloid precursor protein and amyloid- $\beta$ production in vivo. $\mathrm{J} \mathrm{Neu}$ rochem 100: 802-809.

Ittner LM, Ke YD, Delerue F, Bi M, Gladbach A, van Eersel J, Wolfing H, Chieng BC, Christie MJ, Napier IA, et al. 2010. Dendritic function of tau mediates amyloid- $\beta$ toxicity in Alzheimer's disease mouse models. Cell 142: 387-397.

Keller JN, Hanni KB, Markesbery WR. 2000. Impaired proteasome function in Alzheimer's disease. J Neurochem 75: 436-439.
Kim DY, Gersbacher MT, Inquimbert P, Kovacs DM. 2011. Reduced sodium channel $\mathrm{Na}_{\mathrm{v}} 1.1$ levels in BACE1-null mice. J Biol Chem 286: 8106-8116.

Kitazawa M, Oddo S, Yamasaki TR, Green KN, LaFerla FM. 2005. Lipopolysaccharide-induced inflammation exacerbates tau pathology by a cyclin-dependent kinase 5mediated pathway in a transgenic model of Alzheimer's disease. J Neurosci 25: 8843-8853.

Kokubo H, Kayed R, Glabe CG, Yamaguchi H. 2005. Soluble $A \beta$ oligomers ultrastructurally localize to cell processes and might be related to synaptic dysfunction in Alzheimer's disease brain. Brain Res 1031: 222-228.

Kuo YM, Emmerling MR, Vigo-Pelfrey C, Kasunic TC, Kirkpatrick JB, Murdoch GH, Ball MJ, Roher AE. 1996. Water-soluble $A \beta(\mathrm{N}-40, \mathrm{~N}-42)$ oligomers in normal and Alzheimer disease brains. J Biol Chem 271: 4077-4081.

LaFerla FM, Green KN, Oddo S. 2007. Intracellular amyloid- $\beta$ in Alzheimer's disease. Nat Rev Neurosci 8: 499-509.

Laird FM, Cai H, Savonenko AV, Farah MH, He K, Melnikova T, Wen H, Chiang HC, Xu G, Koliatsos VE, et al. 2005. BACE1, a major determinant of selective vulnerability of the brain to amyloid- $\beta$ amyloidogenesis, is essential for cognitive, emotional, and synaptic functions. J Neurosci 25: 11693-11709.

Lee DC, Sunnarborg SW, Hinkle CL, Myers TJ, Stevenson MY, Russell WE, Castner BJ, Gerhart MJ, Paxton RJ, Black RA, et al. 2003. TACE/ADAM17 processing of EGFR ligands indicates a role as a physiological convertase. Ann NY Acad Sci 995: 22-38.

Lee JH, Yu WH, Kumar A, Lee S, Mohan PS, Peterhoff CM, Wolfe DM, Martinez-Vicente M, Massey AC, Sovak G, et al. 2010. Lysosomal proteolysis and autophagy require presenilin 1 and are disrupted by Alzheimer-related PS1 mutations. Cell 141: 1146-1158.

Lerchner A, Machauer R, Betschart C, Veenstra S, Rueeger H, McCarthy C, Tintelnot-Blomley M, Jaton AL, Rabe S, Desrayaud S, et al. 2010. Macrocyclic BACE-1 inhibitors acutely reduce $A \beta$ in brain after po application. Bioorg Med Chem Lett 20: 603-607.

Lewis J, Dickson DW, Lin WL, Chisholm L, Corral A, Jones G, Yen SH, Sahara N, Skipper L, Yager D, et al. 2001. Enhanced neurofibrillary degeneration in transgenic mice expressing mutant tau and APP. Science 293: 1487-1491.

Luo Y, Bolon B, Kahn S, Bennett BD, Babu-Khan S, Denis P, Fan W, Kha H, Zhang J, Gong Y, et al. 2001. Mice deficient in BACE1, the Alzheimer's $\beta$-secretase, have normal phenotype and abolished $\beta$-amyloid generation. Nature Neurosci 4: 231-232.

Marighetto A, Valerio S, Desmedt A, Philippin JN, TrocmeThibierge C, Morain P. 2008. Comparative effects of the $\alpha 7$ nicotinic partial agonist, S 24795, and the cholinesterase inhibitor, donepezil, against aging-related deficits in declarative and working memory in mice. Psychopharmacol (Berl) 197: 499-508.

McGowan E, Pickford F, Kim J, Onstead L, Eriksen J, Yu C, Skipper L, Murphy MP, Beard J, Das P, et al. 2005. A 42 is essential for parenchymal and vascular amyloid deposition in mice. Neuron 47: 191-199.

McLaurin J, Kierstead ME, Brown ME, Hawkes CA, Lambermon MH, Phinney AL, Darabie AA, Cousins JE, French 
F.M. LaFerla and K.N. Green

JE, Lan MF, et al. 2006. Cyclohexanehexol inhibitors of $\mathrm{A} \beta$ aggregation prevent and reverse Alzheimer phenotype in a mouse model. Nature Med 12: 801-808.

Medhurst AD, Atkins AR, Beresford IJ, Brackenborough K, Briggs MA, Calver AR, Cilia J, Cluderay JE, Crook B, Davis JB, et al. 2007. GSK189254, a novel H3 receptor antagonist that binds to histamine $\mathrm{H} 3$ receptors in Alzheimer's disease brain and improves cognitive performance in preclinical models. J Pharmacol Exp Ther 321: $1032-1045$.

Mehlhorn G, Hollborn M, Schliebs R. 2000. Induction of cytokines in glial cells surrounding cortical $\beta$-amyloid plaques in transgenic Tg2576 mice with Alzheimer pathology. Int J Dev Neurosci 18: 423-431.

Meyer-Luehmann M, Stalder M, Herzig MC, Kaeser SA, Kohler E, Pfeifer M, Boncristiano S, Mathews PM, Mercken M, Abramowski D, et al. 2003. Extracellular amyloid formation and associated pathology in neural grafts. Nat Neurosci 6: 370-377.

Meyer-Luehmann M, Coomaraswamy J, Bolmont T, Kaeser S, Schaefer C, Kilger E, Neuenschwander A, Abramowski D, Frey P, Jaton AL, et al. 2006. Exogenous induction of cerebral $\beta$-amyloidogenesis is governed by agent and host. Science 313: 1781-1784.

Meyer-Luehmann M, Spires-Jones TL, Prada C, GarciaAlloza M, de Calignon A, Rozkalne A, KoenigsknechtTalboo J, Holtzman DM, Bacskai BJ, Hyman BT. 2008. Rapid appearance and local toxicity of amyloid- $\beta$ plaques in a mouse model of Alzheimer's disease. Nature 451: 720-724.

Morgan D. 2006. Immunotherapy for Alzheimer's disease. J Alzheimers Dis 9: 425-432.

Mori C, Spooner ET, Wisniewsk KE, Wisniewski TM, Yamaguch H, Saido TC, Tolan DR, Selkoe DJ, Lemere CA 2002. Intraneuronal $A \beta 42$ accumulation in Down syndrome brain. Amyloid 9: 88-102.

Nagy Z, Esiri MM, Jobst KA, Morris JH, King EM, McDonald B, Litchfield S, Smith A, Barnetson L, Smith AD 1995. Relative roles of plaques and tangles in the dementia of Alzheimer's disease: Correlations using three sets of neuropathological criteria. Dementia 6: 21-31.

Naslund J, Haroutunian V, Mohs R, Davis KL, Davies P, Greengard P, Buxbaum JD. 2000. Correlation between elevated levels of amyloid $\beta$-peptide in the brain and cognitive decline. JAMA 283: 1571-1577.

Neely KM, Green KN, LaFerla FM. 2011. Presenilin is necessary for efficient proteolysis through the autophagylysosome system in a $\gamma$-secretase-independent manner J Neurosci 31: 2781-2791.

Oddo S. 2008. The ubiquitin-proteasome system in Alzheimer's disease. J Cell Mol Med 12: 363-373.

Oddo S, Caccamo A, Kitazawa M, Tseng BP, LaFerla FM 2003a. Amyloid deposition precedes tangle formation in a triple transgenic model of Alzheimer's disease. $\mathrm{Neu}$ robiol Aging 24: 1063-1070.

Oddo S, Caccamo A, Shepherd JD, Murphy MP, Golde TE, Kayed R, Metherate R, Mattson MP, Akbari Y, LaFerla FM. 2003b. Triple-transgenic model of Alzheimer's disease with plaques and tangles: Intracellular $A \beta$ and synaptic dysfunction. Neuron 39: 409-421.

Oddo S, Billings L, Kesslak JP, Cribbs DH, LaFerla FM. 2004. $A \beta$ immunotherapy leads to clearance of early, but not late, hyperphosphorylated tau aggregates via the proteasome. Neuron 43: 321-332.

Ohno M, Sametsky EA, Younkin LH, Oakley H, Younkin SG, Citron M, Vassar R, Disterhoft JF. 2004. BACE1 deficiency rescues memory deficits and cholinergic dysfunction in a mouse model of Alzheimer's disease. Neuron 41: 27-33.

Palop J, Chin J, Roberson ED, Wang J, Thwin MT, Bien-Ly N, Yoo J, Ho KO, Yu GQ, Kreitzer A, et al. 2007. Aberrant excitatory neuronal activity and compensatory remodeling of inhibitory hippocampal circuits in mouse models of Alzheimer's disease. Neuron 55: 697-711.

Puzzo D, Staniszewski A, Deng SX, Privitera L, Leznik E, Liu S, Zhang H, Feng Y, Palmeri A, Landry DW, et al. 2009. Phosphodiesterase 5 inhibition improves synaptic function, memory, and amyloid- $\beta$ load in an Alzheimer's disease mouse model. J Neurosci 29: 8075-8086.

Roberds SL, Anderson J, Basi G, Bienkowski MJ, Branstetter DG, Chen KS, Freedman SB, Frigon NL, Games D, Hu K, et al. 2001. BACE knockout mice are healthy despite lacking the primary $\beta$-secretase activity in brain: Implications for Alzheimer's disease therapeutics. Human Mol Genet 10: 1317-1324.

Roberson ED, Scearce-Levie K, Palop JJ, Yan F, Cheng IH, Wu T, Gerstein H, Yu GQ, Mucke L. 2007. Reducing endogenous tau ameliorates amyloid $\beta$-induced deficits in an Alzheimer's disease mouse model. Science 316: $750-754$.

Sankaranarayanan S, Holahan MA, Colussi D, Crouthamel MC, Devanarayan V, Ellis J, Espeseth A, Gates AT, Graham SL, Gregro AR, et al. 2009. First demonstration of cerebrospinal fluid and plasma A $\beta$ lowering with oral administration of a $\beta$-site amyloid precursor proteincleaving enzyme 1 inhibitor in nonhuman primates. J Pharmacol Exp Ther 328: 131-140.

Savonenko AV, Melnikova T, Laird FM, Stewart KA, Price DL, Wong PC. 2008. Alteration of BACE1-dependent NRG1/ErbB4 signaling and schizophrenia-like phenotypes in BACE1-null mice. Proc Natl Acad Sci 105: $5585-5590$.

Schenk D, Barbour R, Dunn W, Gordon G, Grajeda H, Guido T, Hu K, Huang J, Johnson-Wood K, Khan K, et al. 1999. Immunization with amyloid- $\beta$ attenuates Alzheimer-disease-like pathology in the PDAPP mouse. Nature 400: 173-177.

Schor NF. 2011. What the halted phase III $\gamma$-secretase inhibitor trial may (or may not) be telling us. Ann Neurol 69: 237-239.

Shen J, Bronson RT, Chen DF, Xia W, Selkoe DJ, Tonegawa S. 1997. Skeletal and CNS defects in Presenilin-1-deficient mice. Cell 89: 629-639.

Shipton OA, Leitz JR, Dworzak J, Acton CE, Tunbridge EM, Denk F, Dawson HN, Vitek MP, Wade-Martins R, Paulsen O, et al. 2011. Tau protein is required for amyloid $\beta$-induced impairment of hippocampal long-term potentiation. J Neurosci 31: 1688-1692.

Sinha S, Anderson JP, Barbour R, Basi GS, Caccavello R, Davis D, Doan M, Dovey HF, Frigon N, Hong J, et al. 1999. Purification and cloning of amyloid precursor protein $\beta$-secretase from human brain. Nature 402: 537-540. 
Steele M, Stuchbury G, Munch G. 2007. The molecular basis of the prevention of Alzheimer's disease through healthy nutrition. Exp Gerontol 42: 28-36.

Takei Y, Teng J, Harada A, Hirokawa N. 2000. Defects in axonal elongation and neuronal migration in mice with disrupted tau and map1b genes. J Cell Biol 150: 989-1000.

Terry RD, Masliah E, Salmon DP, Butters N, DeTeresa R, Hil R, Hansen LA, Katzman R. 1991. Physical basis of cognitive alterations in Alzheimer's disease: Synapse loss is the major correlate of cognitive impairment. Ann Neurol 30: 572-580.

Tomic JL, Pensalfini A, Head E, Glabe CG. 2009. Soluble fibrillar oligomer levels are elevated in Alzheimer's disease brain and correlate with cognitive dysfunction. Neurobiol Dis 35: 352-358.

Vassar R, Bennett BD, Babu-Khan S, Kahn S, Mendiaz EA, Denis P, Teplow DB, Ross S, Amarante P, Loeloff R et al. 1999. $\beta$-Secretase cleavage of Alzheimer's amyloid precursor protein by the transmembrane aspartic protease BACE. Science 286: 735-741.

Verhoest PR, Proulx-Lafrance C, Corman M, Chenard L, Helal CJ, Hou X, Kleiman R, Liu S, Marr E, Menniti FS, et al. 2009. Identification of a brain penetrant PDE9A inhibitor utilizing prospective design and chemical enablement as a rapid lead optimization strategy. J Med Chem 52: 7946-7949.

Walsh DM, Selkoe DJ. 2007. A $\beta$ oligomers-A decade of discovery. J Neurochem 101: 1172-1184.

Wang J, Dickson DW, Trojanowski JQ, Lee VM. 1999. The levels of soluble versus insoluble brain $A \beta$ distinguish Alzheimer's disease from normal and pathologic aging. Exp Neurol 158: 328-337.

Webster SD, Tenner AJ, Poulos TL, Cribbs DH. 1999. The mouse C1q A-chain sequence alters $\beta$-amyloid-induced complement activation. Neurobiol Aging 20: 297-304.

Wilcock DM, Lewis MR, Van Nostrand WE, Davis J, Previti ML, Gharkholonarehe N, Vitek MP, Colton CA. 2008. Progression of amyloid pathology to Alzheimer's disease pathology in an amyloid precursor protein transgenic mouse model by removal of nitric oxide synthase 2 . J Neurosci 28: 1537-1545.

Willem M, Garratt AN, Novak B, Citron M, Kaufmann S, Rittger A, DeStrooper B, Saftig P, Birchmeier C, Haass C. 2006. Control of peripheral nerve myelination by the $\beta$-secretase BACE1. Science 314: 664-666.

Woltjer RL, Sonnen JA, Sokal I, Rung LG, Yang W, Kjerulf JD, Klingert D, Johnson C, Rhew I, Tsuang D, et al. 2009. Quantitation and mapping of cerebral detergentinsoluble proteins in the elderly. Brain Pathol 19: 365374.

Wong HK, Sakurai T, Oyama F, Kaneko K, Wada K, Miyazaki H, Kurosawa M, De Strooper B, Saftig P, Nukina N. 2005. $\beta$ Subunits of voltage-gated sodium channels are novel substrates of $\beta$-site amyloid precursor protein-cleaving enzyme (BACE1) and $\gamma$-secretase. J Biol Chem 280: 23009-23017.

Wyss-Coray T, Mucke L. 2002. Inflammation in neurodegenerative disease-A double-edged sword. Neuron 35: 419-432.

Yamasaki TR, Blurton-Jones M, Morrissette DA, Kitazawa M, Oddo S, LaFerla FM. 2007. Neural stem cells improve memory in an inducible mouse model of neuronal loss. J Neurosci 27: 11925-11933.

Yang F, Ueda K, Chen P, Ashe KH, Cole GM. 2000. Plaque-associated $\alpha$-synuclein (NACP) pathology in aged transgenic mice expressing amyloid precursor protein. Brain Res 853: 381-383.

Zhang YW, Wang R, Liu Q, Zhang H, Liao FF, Xu H. 2007. Presenilin $/ \gamma$-secretase-dependent processing of $\beta$-amyloid precursor protein regulates EGF receptor expression. Proc Natl Acad Sci 104: 10613-10618.

Zheng H, Jiang M, Trumbauer ME, Hopkins R, Sirinathsinghii DJ, Stevens KA, Conner MW, Slunt HH, Sisodia SS, Chen HY, et al. 1996. Mice deficient for the amyloid precursor protein gene. Ann NYAcad Sci 777: 421-426. 


\section{$\&_{\mathrm{CSH}}^{\infty} \&$ Cold Spring Harbor

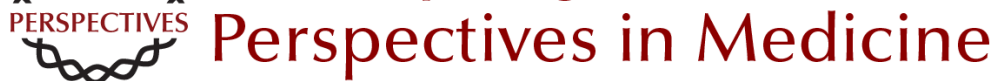

\section{Animal Models of Alzheimer Disease}

Frank M. LaFerla and Kim N. Green

Cold Spring Harb Perspect Med 2012; doi: 10.1101/cshperspect.a006320 originally published online September 21, 2012

\section{Subject Collection The Biology of Alzheimer Disease}

Animal Models of Alzheimer Disease

Frank M. LaFerla and Kim N. Green

Neurovascular Dysfunction and Faulty Amyloid $\beta$

-Peptide Clearance in Alzheimer Disease Abhay P. Sagare, Robert D. Bell and Berislav V. Zlokovic

Treatment Strategies Targeting Amyloid $\beta$-Protein Dale Schenk, Guriqbal S. Basi and Menelas N. Pangalos

The Ubiquitin-Proteasome System and the Autophagic-Lysosomal System in Alzheimer Disease

Yasuo Ihara, Maho Morishima-Kawashima and Ralph Nixon

Neurotoxicity of Amyloid $\beta$-Protein: Synaptic and Network Dysfunction Lennart Mucke and Dennis J. Selkoe

Proteolytic Degradation of Amyloid $\beta$-Protein Takaomi Saido and Malcolm A. Leissring

Brain Imaging in Alzheimer Disease

Keith A. Johnson, Nick C. Fox, Reisa A. Sperling, et al.

Symptomatic and Nonamyloid/Tau Based Pharmacologic Treatment for Alzheimer Disease Paul S. Aisen, Jeffrey Cummings and Lon S. Schneider
Alzheimer Disease in 2020

David M. Holtzman, Eckhard Mandelkow and

Dennis J. Selkoe

The Genetics of Alzheimer Disease Rudolph E. Tanzi

Fluid Biomarkers in Alzheimer Disease

Kaj Blennow, Henrik Zetterberg and Anne M. Fagan

Epidemiology of Alzheimer Disease

Richard Mayeux and Yaakov Stern

Biochemistry and Cell Biology of Tau Protein in Neurofibrillary Degeneration

Eva-Maria Mandelkow and Eckhard Mandelkow

Biochemistry of Amyloid $\beta$-Protein and Amyloid Deposits in Alzheimer Disease

Colin L. Masters and Dennis J. Selkoe

The Neuropsychological Profile of Alzheimer

Disease

Sandra Weintraub, Alissa H. Wicklund and David P. Salmon

Apolipoprotein E and Apolipoprotein E Receptors: Normal Biology and Roles in Alzheimer Disease David M. Holtzman, Joachim Herz and Guojun Bu

For additional articles in this collection, see http://perspectivesinmedicine.cshlp.org/cgi/collection/ 